\title{
INHIBITORY POTENTIAL OF MURRAYA KOENIGII (L.) AND FICUS CARICA L. EXTRACTS AGAINST ALDOSE REDUCTASE (ALR), ADVANCED GLYCATION END PRODUCTS (AGES) FORMATION AND SORBITOL ACCUMULATION
}

\author{
Shah Asma Farooq ${ }^{1}$, Randhir Singh ${ }^{1}$ \\ ${ }^{I}$ M.M. College of Pharmacy, Maharishi Markandeshwar (Deemed to be) University, Mullana, Ambala, Haryana, India, 133207.
}

\section{INHIBITORNI POTENCIJAL EKSTRAKTA MURRAYA KOENIGII (L.) I FICUS CARICA L. NA ALDOZA REDUKTAZU (ALR), STVARANJE NAPREDNIH GLIKACIONIH KRAJNJIH PROIZVODA (AGES) I AKUMULACIJU SORBITOLA \\ Shah Asma Farooq ${ }^{1}$, Randhir Singh ${ }^{1}$ \\ ${ }^{I}$ M.M Farmaceutski fakultet, Maharishi Markandeshwar Univerzitet, Mullana, Ambala, Haryana, India, 133207}

\begin{abstract}
Introduction: Murraya koenigii (L.) and Ficus carica L. are traditionally used plants with significant medicinal and nutritional values. Aim and Objective: The present study was focused on the evaluation of hydro-alcoholic and aqueous extracts of $M$. koenigii (L.) leaves [MKHA (M. koenigii (L.) hydro-alcoholic extract) and $M K A Q$ (M .koenigii (L.) aqueous extract)] and dried fruits of F. carica L. [FCHA (F. carica L. hydro-alcoholic extract) and FCAQ (F. carica L. aqueous extract)] in the attenuation of markers of microvascular complications associated with diabetes mellitus which can be further used to investigate the pharmacological activity of these plants in treatment of diabetes and its complications. Material and Method: The attenuating effect of the extracts was evaluated by calculating the ALRI enzyme inhibition in a kidney of Wistar rat, anti-glycation activity in bovine serum albumin (BSA) and erythrocyte sorbitol accumulation inhibition in heparinized human blood. Results: A significant inhibitory effect $\left(I C_{50} 6.47 \mu \mathrm{g} / \mathrm{ml}, 7.26 \mu \mathrm{g} / \mathrm{ml}, 8.93 \mu \mathrm{g} / \mathrm{ml}\right.$ and $\left.9.66 \mu \mathrm{g} / \mathrm{ml}\right)$ was observed with different concentrations of extracts (MKHA, $M K A Q, F C H A$ and $F C A Q$ ) respectively, against ALR enzyme. After the $4^{\text {th }}$ week of incubation, the inhibition of AGEs formation by MKHA, MKAQ, FCHA and FCAQ $(500 \mu \mathrm{g} / \mathrm{ml})$ was found to be $82.58 \%, 78.58 \%, 74.39 \%$ and $69.56 \%$ respectively. МKHA, $M K A Q, F C H A$ and FCAQ were found to exhibit significant inhibition against the accumulation of sorbitol in RBCs with $I C_{50}$ $188.88 \mu \mathrm{g} / \mathrm{ml}, 247.74 \mu \mathrm{g} / \mathrm{ml}, 291.94 \mu \mathrm{g} / \mathrm{ml}$ and $345.34 \mu \mathrm{g} / \mathrm{ml}$, respectively. Conclusion: The administration of different concentrations of MKHA, MKAQ, FCHA and FCAQ significantly attenuated ALR, AGEs and sorbitol accumulation; hence, it can provide a basis for identification and development of new inhibitors of these biomarkers.
\end{abstract}

Keywords: ALR inhibition, AGEs formation, Sorbitol accumulation, Ficus carica, Murraya koenigii.

\section{SAŽETAK}

Uvod: Murraya koenigii (L.) i Ficus carica L su tradicionalno korišćene biljke sa značajnom lekovitom i nutritivnom vrednošću. Cilj: Ova studija je fokusirana na proceni hidro-alkoholnih $i$ vodenih ekstrakta listova M. koenigii (L.) [MKHA (M. koenigii (L.) hidro-alkoholni ekstrakt) i MKAQ (M .koenigii (L.) vodeni ekstrakt) $i$ sušenih plodova F. carica L. [FCHA (F. carica L. hidro-alkoholni ekstrakt) i FCAQ (F. carica L. vodeni ekstrakt)] u slabljenju markera mikrovaskularnih kompikacija povezanih sa dijabetesom melitusom što se može dalje koristiti da bi se ispitalo farmakološko dejstvo ovih biljaka u lečenju dijabetesa i njegovih komplikacija. Materijali i metode: Ublažavajuće dejstvo ekstrakta je procenjeno proračunom inhibicije ALR1 enzima u bubregu Wistar pacova, antiglikacionog dejstva u goveđem serumskom albuminu (BSA) i inhibicije akumulacije sorbitola u heparinizovanoj humanoj krvi. Rezultati: Značajan inhibitorni efekat $\left(I_{50}\right.$ $6.47 \mu \mathrm{g} / \mathrm{ml}, 7.26 \mu \mathrm{g} / \mathrm{ml}, 8.93 \mu \mathrm{g} / \mathrm{ml}$ i $9.66 \mu \mathrm{g} / \mathrm{ml})$ je primećen sa različitim koncentracijama ekstrakta (MKHA, MKAQ, FCHA $i$ FCAQ) na ALR enzim. Posle četvrte nedelje inkubacije, inhibicija stvaranja AGEs pomoću MKHA, MKAQ, FCHA i FCAQ $(500 \mu \mathrm{g} / \mathrm{ml})$ je bila $82.58 \%, 78.58 \%, 74.39 \%$ i 69.56\%. МКHA, MKAQ, FCHA i FCAQ su pokazali značajnu inhibiciju na akumulaciju sorbitola u RBCs sa IC $C_{50} 188.88 \mu \mathrm{g} / \mathrm{ml}, 247.74 \mu \mathrm{g} / \mathrm{ml}$, $291.94 \mu \mathrm{g} / \mathrm{ml}$ i $345.34 \mu \mathrm{g} / \mathrm{ml}$. Zaključak: Primena različitih koncentracija MKHA, MKAQ, FCHA i FCAQ značajno je oslabila ALR, AGEs i akumulaciju sorbitola, stoga, ona može da obezbedi osnovu za prepoznavanje $i$ razvoj novih inhibitora ovih biomarkera.

Ključne reči: ALR inhibicija, stvaranje AGEs, akumulacija sorbitola, Ficus carica; Murraya koenigii.

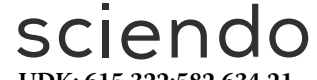

UDK: 615.322:582.634.21 615.322:582.745.19

Ser J Exp Clin Res 2021; 22 (2): 125-130 DOI: $10.2478 /$ sjecr-2020-0056
Corresponding author: Dr. Randhir Singh

Department of Pharmacology, M M College of Pharmacy, M M (Deemed to be University), Mullana, Ambala,
Haryana, India, 133207
E-mail: randhirsingh.dahiya@gmail.com
Mobile No.9896029234 M M (Deemed to be University), Mullana, Ambala,
Haryana, India, 133207
E-mail: randhirsingh.dahiya@gmail.com
Mobile No.9896029234 M M (Deemed to be University), Mullana, Ambala,
Haryana, India, 133207
E-mail: randhirsingh.dahiya@gmail.com
Mobile No.9896029234 Mobile No. 9896029234 


\section{INTRODUCTION}

Diabetes mellitus (DM) is a chronic, progressive and metabolic disease resulting in chronic hyperglycemia as well as altered metabolism of carbohydrates, proteins and fats and a number of people affected by diabetes is expected to increase to 354 million by 2030 (1-3). Diabetes is also responsible for many short and long-term complications like diabetic neuropathy, retinopathy and nephropathy (2). Development of diabetic complications is triggered by hyperglycemia. Moreover, in chronic diabetes, there is an initiation of various metabolic pathways (hexosamine; mitogenactivated protein kinases (MAPKs); sorbitol-aldose reductase; protein kinase C; advanced glycation end products (AGEs), their receptors and nitric oxide synthase) (4-8). Formation of AGEs leads to damage of target cells (9) prompting receptor-mediated liberation of reactive oxygen species (ROS) (10). Aldehyde reductase (ALR), advanced glycation end products (AGEs) and sorbitol are prominent markers of diabetic complications. Reduction of aldehydes and carbonyls is caused due to activity of ALR, which is a key enzyme for aldehyde detoxification, osmotic regulation, and metabolism of catecholamines and steroids under normal physiological conditions (11). During glucose metabolism, a number of proteins or lipids are produced called as AGEs, which become glycated upon exposure to sugar, causing various diseases like diabetes, atherosclerosis, etc. (7). ALR also reduces glucose to a slow metabolizing alcoholic sugar (sorbitol) which produces a laxative effect by drawing water into the large intestine (12).

Interaction of AGEs and its receptors produces oxidative stress, which leads to the damage and vascular aging. During hyperglycemic conditions, the reduction of glucose to sorbitol is caused by the consumption of cofactor nicotinamide adenine dinucleotide phosphate (NADPH) by ALR. This overexploitation of NADPH affects other homeostatic mechanisms, such as the glutathione (GSH) production; an antioxidant enzyme, which further leads to oxidative stress. There is the accumulation of excessive sorbitol and extracellular glucose in several sensitive tissues such as eye lenses, retinal cells, peripheral nerves, renal cells, etc. which ultimately causes long-term complications. Hence, the therapeutic agents that can inhibit ALR, AGEs formation and sorbitol accumulation may have a therapeutic potential for treating diabetic complications $(13,14)$.

Murraya koenigii (L.) Sprengel, (Rutaceae), has been used in folk and traditional medicine for treating a traumatic injury, snake bite, rheumatism, as a stimulant, and in the management of diabetes mellitus (15). Various phytoconstituents (alkaloids and coumarin glycoside) present in the leaves of M. koenigii were found to possess antioxidant, antihyperlipidemic, antifungal, antibacterial, larvicidal, anti-carcinogenic, anti-hyperglycemic, anti-lipid peroxidative, and hypotensive activity (16). The various chemical constituents found in the leaves of M. koenigii are: Alkaloids: mahanine, koenine, koenigine, koenidine, girinimbiol, girinimibine, koenimbine, O-methyl murrayamine A, O-methyl mahanine, isomahanine, bismahanine, bispyrayafoline. Coumarin glycoside: scopotin, murrayanine. Essential oil: di- alpha phellandrene, D-pinene, D-sabinene, D-terpinol, dipentene and caryophyllene. 5, 8-dimethyl furanocoumarin, 1-al, 3[6', 6' dimethyl 5-hexene] carbazole, $\beta$-sitosterol. Phosphorus, iron, thiamine, riboflavin, niacin, vitamin c, carotene, oxalic acid and calcium (17-18).

Ficus carica Linn. (Moraceae), is used in Ayurveda, homoeopathy and siddha system of medicine (19). The bark, leaves and fruits are traditionally used to treat different disorders such as respiratory diseases, gastrointestinal diseases, diabetes, skin diseases, ulcers, dysentery and haemorrhoids (20). F. carica has anti-inflammatory, cytotoxic, and anti-hyperlipidemic activities. Various phytoconstituents such as amino acids, phytosterols, anthocyanins, organic acid, hydrocarbons, aliphatic alcohols, volatile components, fatty acids, phenolic components, etc. have been isolated from different parts of $F$. carica $(21,22)$. Psoralen, bergapten, umbelliferone, $\beta$-sitosterol, campesterol, stigmasterol, fucosterol, fatty acids, 6-(2-methoxy-Z-vinyl)-7-methyl-pyranocoumarin, 9, 19-cycloarlane triterpenoid, 6-O-acyl- $\beta$-Dglucosyl- $\beta$-sitosterol,calotropenyl acetate, lupeol acetate and a few other classes of secondary metabolites (23).

Many active and potent synthetic ALR inhibitors and AGE inhibitors have been synthesized by many researchers but they did not pass clinical trials due to their poor pharmacokinetics, low efficacy and safety. Therefore, the focus has been shifted towards herbal drugs to explore new agents with better efficacy and lesser side effects (24-26). So, this study was designed to investigate the inhibitory activity of hydroalcoholic and aqueous extracts of $M$. koenigii and F. carica against ALR, AGEs and sorbitol accumulation.

\section{MATERIALS AND METHODS}

\section{Plant material used}

Fresh leaves of M. koenigii (L.) were collected in August - September from the herbal garden of Maharishi Markandeshwer College of Pharmacy (MMCP), Maharishi Markandeshwer (Deemed to be) University, Mullana Ambala, Haryana and dried fruits of $F$. carica $\mathrm{L}$. were collected from a local market of Ambala, Haryana and authenticated by Dr. K. Madhava Chetty from the Department of Botany, Sri Vankateshwara University, Tirupati, India. The plant specimen voucher numbers 0384 and 1296 are present in the herbarium of the University for future reference.

\section{Reagents used}

Ethanol, NADPH (nicotinamide adenine dinucleotide phosphate), Glyceraldehyde, Bovine serum albumin (BSA), Aminoguanidine, Heparinized human blood, NADH (Nicotinamide adenine dinucleotide), Fructose, Ascorbic acid.

\section{Preparation of Extracts}

The fresh leaves of $M$. koenigii (L.) were shadedried and crushed to powder. $100 \mathrm{~g}$ of the powdered leaves were first 
extracted with aqueous ethanol (40\%) and then with water for 48 hours by maceration with the aid of an electric magnetic stirrer. Also, the fruits of F.carica L. were further dried and powdered. $100 \mathrm{~g}$ of the powdered fruits were extracted by maceration sequentially using hydro-alcohol i.e. aqueous ethanol (40\%) and water for 48 hours by using an electric magnetic stirrer. The extracts were filtered and concentrated at the temperature of $40^{\circ} \mathrm{C}$ by using a rotary evaporator under the reduced pressure. The extraction yield was calculated and the crude extracts were dissolved in water and used for the assessment of various assays.

\section{ALR1 enzyme inhibition}

The fractional purification of ALR1 enzyme was carried out from the kidney of a rat (IAEC Protocol No.: MMCP/IAEC/24). The activity of ALR1 was calculated by checking the oxidation of NADPH and was assessed spectrophotometrically at $340 \mathrm{~nm}$ at $37^{\circ} \mathrm{C}$ as an element of time. Glyceraldehyde was used as a substrate for the estimation of ALR1 enzyme inhibition.

The $\mathrm{IC}_{50}$ values were calculated by plotting the percent inhibition versus the inhibition concentration (27). The experiment was done in triplicate.

\section{Anti-glycation activity}

In-vitro anti-glycation activity of the extracts was estimated by measuring the capability of extracts in inhibiting fluorescence of bovine serum albumin (BSA) on a weekly basis up to four weeks, Matsuda et al. (28). Aminoguanidine was considered as a reference compound. The formation of AGEs was measured from the intensity of fluorescence at the excitation wavelength of $355 \mathrm{~nm}$ and emission wavelength of $460 \mathrm{~nm}$. Elico-SLI74 Spectrofluorometer was employed for determination of the anti-glycation activity. The experiment was done in triplicate.

\section{Erythrocyte sorbitol accumulation inhibition}

The inhibition of accumulation of sorbitol in erythrocytes was estimated according to the method of Haraguchi et al. in which $5 \mathrm{ml}$ of human blood (heparinized) was taken from a healthy male volunteer kept overnight fasting. Erythrocytes were isolated then from plasma by centrifugation (29). ElicoSLI74 Spectrofluorometer was used to measure the relative fluorescence due to NADH at the excitation wavelength of $366 \mathrm{~nm}$ and emission wavelength of $452 \mathrm{~nm}$.

\section{RESULTS}

\section{Extraction yield of the extracts:}

The extraction yield of hydro-alcoholic extract of $M$. koenigii (MKHA) was found to be $24.45 \%$ and the extraction yield of aqueous extract of $M$. koenigii (MKAQ) was found to be $17.7 \%$ Whereas, the extraction yield of hydro-alcoholic extract of $F$. carica (FCHA) was found to be $34.57 \%$, the extraction yield of aqueous extract of $F$. carica (FCAQ) was found to be $28.42 \%$.

\section{Inhibition of ALR}

ALR enzyme was isolated from the kidney of Wistar rat and the activity of ALR was monitored spectrophotometrically by measuring the oxidation of NADPH at $340 \mathrm{~nm}$. Different concentrations $(2,4,6,8,10 \mu \mathrm{g} / \mathrm{ml})$ of MKHA, MKAQ, FCHA and FCAQ produced a good inhibitory effect against ALR enzyme with $\mathrm{IC}_{50} 6.47 \mu \mathrm{g} / \mathrm{ml}, 7.26 \mu \mathrm{g} / \mathrm{ml}, 8.93$ $\mu \mathrm{g} / \mathrm{ml}$ and $9.66 \mu \mathrm{g} / \mathrm{ml}$ respectively whereas, $\mathrm{IC}_{50}$ of quercetin (standard) was found to be $4.87 \mu \mathrm{g} / \mathrm{ml}$. (Figure 1)

Figure 1. Inhibitory effects of MKHA, MKAQ, FCHA and FCAQ against ALR enzyme inhibition



\section{Inhibition of AGEs}

The production of AGEs was observed on a weekly basis by measuring the intensity of fluorescence of BSA-fructose solutions for 4 weeks and MKHA, MKAQ, FCHA and FCAQ (the concentration 25, 50, 100, 200, 400, $500 \mu \mathrm{g} / \mathrm{ml}$ ) significantly attenuated the production of AGEs. After the 4th week of incubation, the inhibition of AGEs formation by aminoguanidine (standard) $(500 \mu \mathrm{g} / \mathrm{ml})$ was found to be $97.53 \%$ whereas the percentage inhibition by MKHA, MKAQ, FCHA and FCAQ $(500 \mu \mathrm{g} / \mathrm{ml})$ was found to be $82.58 \%, 78.58 \%, 74.39 \%$ and $69.56 \%$ of AGEs formations respectively (Figure 2, 3, 4 and 5).

Figure 2. Inhibitory effect of MKHA against AGEs inhibition

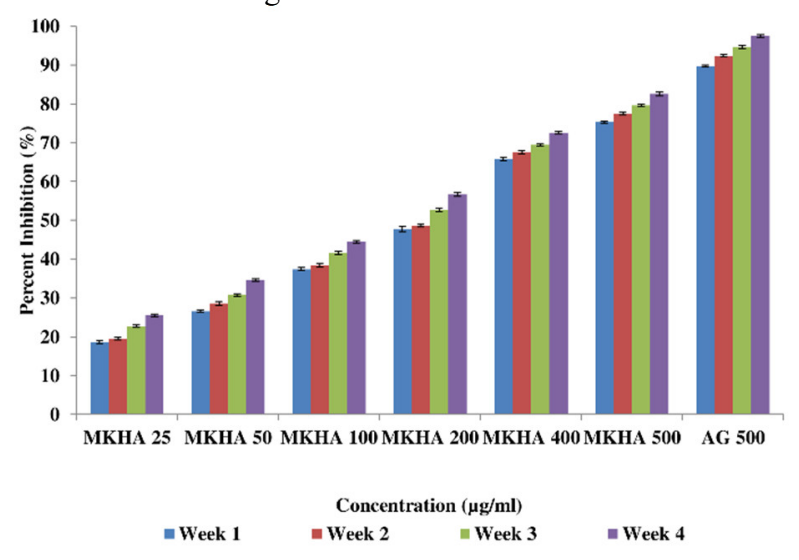




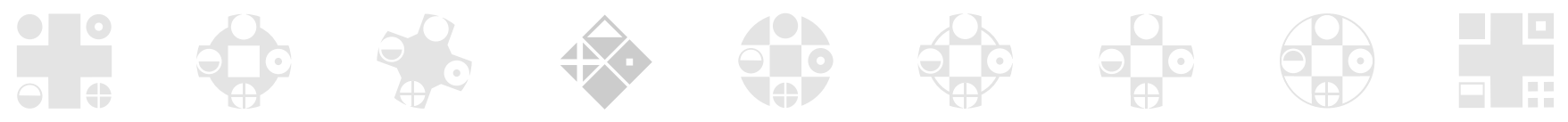

Figure 3. Inhibitory effect of MKAQ against AGEs inhibition

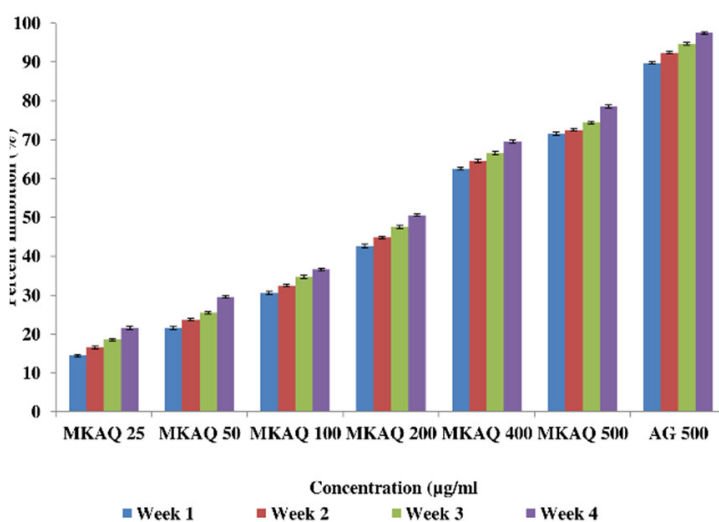

Figure 4. Inhibitory effect of FCHA against AGEs inhibition

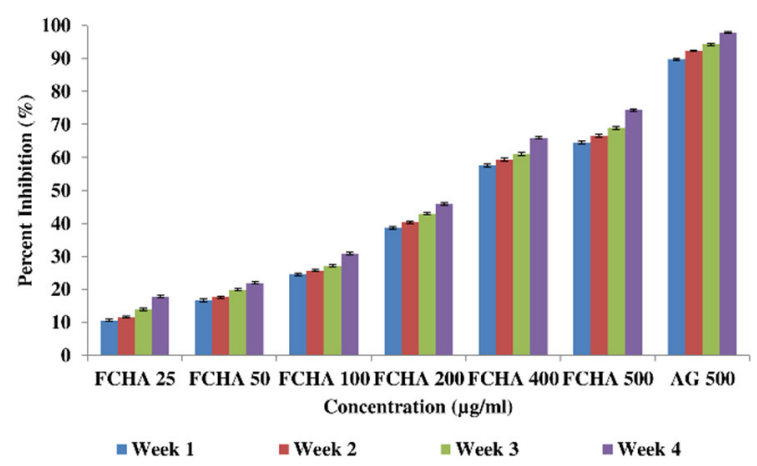

Figure 5. Inhibitory effect of FCAQ against AGEs inhibition

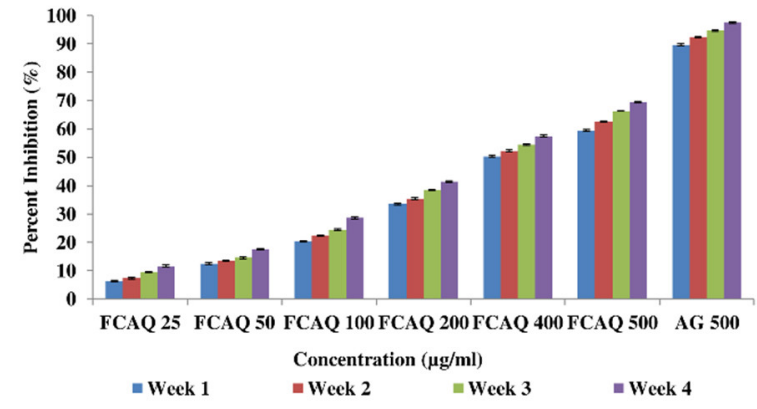

Erythrocyte sorbitol accumulation inhibition

In the present study, different concentrations (12.5, 25, $50,100,200,400,500 \mu \mathrm{g} / \mathrm{ml})$ of MKHA, MKAQ, FCHA and FCAQ were prepared and their effect was measured against the accumulation of sorbitol in terms of relative fluorescence due to NADH. Different concentrations of MKHA, MKAQ, FCHA and FCAQ were found to exhibit the significant inhibition of accumulation of sorbitol in erythrocytes with an $\mathrm{IC}_{50}$ $188.88 \mu \mathrm{g} / \mathrm{ml}, 247.74 \mu \mathrm{g} / \mathrm{ml}, 291.94 \mu \mathrm{g} / \mathrm{ml}$ and $345.34 \mu \mathrm{g} / \mathrm{ml}$ respectively while as $\mathrm{IC}_{50}$ of ascorbic acid was found to be $150.06 \mu \mathrm{g} / \mathrm{ml}$ [Figure 6].
Figure 6. Inhibitory effects of MKHA, MKAQ, FCHA and FCAQ against Sorbitol accumulation

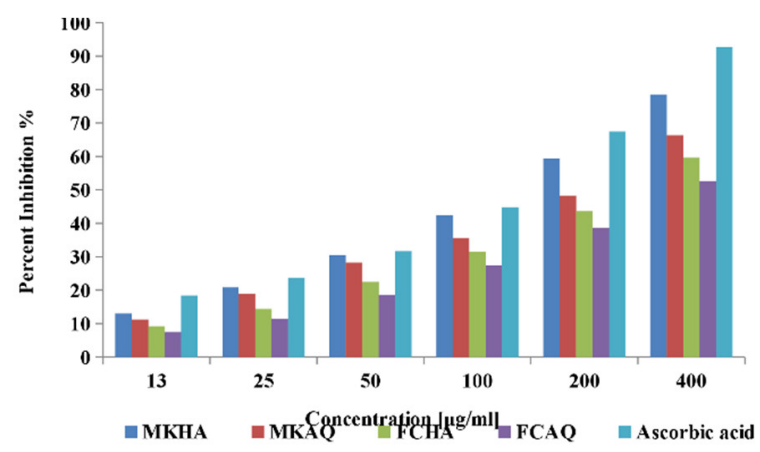

\section{DISSCUSION}

The reduction of aldehydes and carbonyls is caused due to the activity of ALR, which is a key enzyme for aldehyde detoxification, osmotic regulation, and metabolism of catecholamines and steroids under the normal physiological conditions (11). ALR has a low affinity for glucose therefore; its metabolism is not affected under the normal physiological conditions $(14,30)$. During the chronic hyperglycemic conditions, hexokinase enzyme that is responsible for glucose phosphorylation for the production of energy is saturated and the surplus of glucose enters the polyol pathway resulting in the reduction of glucose to sorbitol. During hyperglycemia, ALR consumes cofactor NADPH for reducing glucose to sorbitol. This over-exploitation of NADPH affects other homeostatic mechanisms, such as the glutathione (GSH) production; an antioxidant enzyme, which further leads to oxidative stress (13).

Amadori products (by the reaction of proteins/lipids with reducing sugars) via Mallard reaction are formed because of non-enzymatic glycation due to chronic hyperglycemia. These products are further transformed to cross-linking AGEs like pentosidine and crosslines, having a specific fluorescence. Due to the production of excessive AGEs, the receptors of AGEs (RAGEs) are also overexpressed, which further leads to pathogenesis of diabetic complications. Several studies have confirmed the vital role of inhibition of AGEs leading to the attenuation of diabetic complications (31-34), therefore, the inhibition of AGEs can be proposed as a good therapeutic option to lag the progression of diabetic complications.

ALR also reduces glucose to a slow metabolizing alcoholic sugar (sorbitol) which produces a laxative effect by drawing water into the large intestine (12). The excessive sorbitol formation during the polyol pathway and extracellular glucose gets accumulated in several sensitive tissues such as eye lenses, retinal cells, peripheral nerves, renal cells, etc. which ultimately causes long-term complications $(30,13)$.

MKHA has produced better inhibitory effect against ALR enzyme with $\mathrm{IC}_{50} 6.47 \mu \mathrm{g} / \mathrm{ml}$ than MKAQ which produced $\mathrm{IC}_{50} 7.26 \mu \mathrm{g} / \mathrm{ml}$ and FCHA produced $\mathrm{IC}_{50} 8.93 \mu \mathrm{g} / \mathrm{ml}$ and 
FCAQ produced $\mathrm{IC}_{50} 9.66 \mu \mathrm{g} / \mathrm{ml}$, respectively in comparison to quercetin (standard) i.e. $4.87 \mu \mathrm{g} / \mathrm{ml}$. The higher activity of MKHA as compared to MKAQ, and that of FCHA as compared to FCAQ may be due to the additive effect of higher concentration of different flavonoids present in the hydro-alcoholic extract than the aqueous extracts $(38,39)$. Several researchers have studied the potential of flavonoids against ALR enzyme that encouraged our results $(14,35,36,37)$. In the present study, the formation of AGEs was observed weekly by measuring the fluorescence intensity of bovine serum albumin (BSA)-fructose solutions for subsequent four weeks and MKHA, MKAQ, FCHA and FCAQ were found to have an inhibitory effect against the formation of AGEs. After the 4th week of incubation, the inhibition of AGEs formation by aminoguanidine (standard, $500 \mu \mathrm{g} / \mathrm{ml}$ ) was 97.53 $\%$ whereas MKHA, MKAQ, FCHA and FCAQ $(500 \mu \mathrm{g} / \mathrm{ml})$ inhibited $82.58 \%, 78.58 \%, 74.39 \%$ and $69.56 \%$ of AGEs formations respectively. In the present study, different concentrations of MKHA, MKAQ, FCHA and FCAQ (12.5, 25, $50,100,200,400,500 \mu \mathrm{g} / \mathrm{ml}$ ) were prepared and their effect was measured against sorbitol accumulation in terms of relative fluorescence due to NADH. The different concentrations of MKHA, MKAQ, FCHA and FCAQ were found to exhibit a significant inhibitory effect on the accumulation of sorbitol in red blood cells with an $\mathrm{IC}_{50} 188.88 \mu \mathrm{g} / \mathrm{ml}, 247.74 \mu \mathrm{g} / \mathrm{ml}$, $291.94 \mu \mathrm{g} / \mathrm{ml}$ and $345.34 \mu \mathrm{g} / \mathrm{ml}$ respectively which was comparable to Ascorbic acid i.e. $183.08 \mu \mathrm{g} / \mathrm{ml}$.

\section{CONCLUSION}

This study has revealed the inhibitory potential of hydroalcoholic and aqueous extracts of $M$. koenigii (L.) and $F$. carica L. against ALR enzyme activation, AGEs formation and sorbitol accumulation. Thus, these extracts of $M$. koenigii (L.) and F. carica L. may have a beneficial role to delay the progression of diabetic complications.

\section{CONFLICT OF INTEREST}

The authors have no conflict of interest.

\section{ACKNOWLEDGEMENT}

Authors are thankful to MMDU for providing the facility for work.

\section{REFERENCES}

1. Olokoba AB, Obateru OA, Olokoba LB. Type 2 diabetes mellitus: a review of current trends. Oman Med. J. 2012 Jul; 27(4):269-73.

2. Mehta SR, Kashyap AS, Das S. Diabetes mellitus in India: The modern scourge. Med J. Armed Forces India. 2009 Jan 1; 65(1):50-4.

3. American Diabetes Association. Diagnosis and Classification of Diabetes Mellitus. Diabetes Care, 2014; 37(1).
4. Dunlop M. Aldose reductase and the role of the polyol pathway in diabetic nephropathy. Kidney Int. 2000 Sep 1; 58:S3-12.

5. Koshikawa M, Mukoyama M, Mori K, Suganami T, Sawai K, Yoshioka T, et al. Role of p38 mitogen-activated protein kinase activation in podocyte injury and proteinuria in experimental nephrotic syndrome. Clin J Am Soc Nephrol. 2005 Sep 1; 16(9):2690-701.

6. Meier M, Menne J, Park JK, Haller H. Nailing down $\mathrm{PKC}$ isoform specificity in diabetic nephropathy - two's company, three's a crowd. Nephrol Dial Transplant. 2007; 22:2421-2425.

7. Toth C, Rong LL, Yang C, Martinez J, Song F, Ramji N, et al. Receptor for advanced glycation end products (RAGEs) and experimental diabetic neuropathy. Diabetes. 2008; 57:1002-17.

8. Vareniuk I, Pavlov IA, Obrosova IG. Inducible nitric oxide synthase gene deficiency counteracts multiple manifestations of peripheral neuropathy in a streptozotocininduced mouse model of diabetes. Diabetologia. 2008; 51:2126-33.

9. Brownlee M. Biochemistry and molecular cell biology of diabetic complications. Nature. 2001;414:813-20.

10. Schmidt AM, Yan SD, Wautier JL, Stern D. Activation of receptor for advanced glycation end products: a mechanism for chronic vascular dysfunction in diabetic vasculopathy and atherosclerosis. Circ. Res. 1999 Mar 19; 84(5):489-97.

11. Yabe-Nishimura C. Aldose reductase in glucose toxicity: a potential target for the prevention of diabetic complications. Pharmacol Rev. 1998 Mar 1; 50(1):2134.

12. Reddy GB, Muthenna P, Akileshwari C, Saraswat M, Petrash JM. Inhibition of aldose reductase and sorbitol accumulation by dietary rutin. Curr. Sci. 2011 Nov; 10:1191-7.

13. Singh R, Kishore L, Kaur N. Diabetic peripheral neuropathy: current perspective and future directions. Pharmacol. Res. Commun. 2014 Feb 1; 80:21-35.

14. Jung HA, Jung YJ, Yoon NY, Jeong DM, Bae HJ, Kim DW, et al. Inhibitory effects of Nelumbo nucifera leaves on rat lens aldose reductase, advanced glycation endproducts formation, and oxidative stress. Food Chem. Toxicol. 2008 Dec 1; 46(12):3818-26.

15. Vijayanand S. Evaluation of Antidiabetic activity of Murraya koenigii on Alloxan Induced Diabetic rats. Int. J. Pharm. Sci. Res. 2015; 6(12):1401-05.

16. Saini SC, Reddy GBS. Murraya koenigii. J Pharm Biol Sci. 2013; 7(6):15-18.

17. Vandana J. Murraya Koenigii: An Updated Review. Int. j. Ayurvedic herb. med. 2012; 2(4): 607-627.

18. Saini CS, Reddy GBS. A Review on Curry Leaves (Murraya koenigii): Versatile Multi-Potential Medicinal Plant. American Journal of Phytomedicine and Clinical Therapeutics, 2015; 3(4); 363-368.

19. Stephen IS, Christudas S, Antony S, Duraipandiyan V, Naif AAD, Ignacimuthu S. Protective effects of Ficus carica leaves on glucose and lipids levels, carbohydrate 
metabolism enzymes and $\beta$-cells in type 2 diabetic rats. Pharm. Biol. 2017 Jan 1; 55(1):1074-

20. Tchombe LN, Louajri A. Therapeutic effects of Ficus carica leaves: A brief review. ARPN J. Sci. Technol. 2015; 5:37-41.

21. Badgujar SB, Patel VV, Bandivdekar AH, Mahajan RT. Traditional uses, phytochemistry and pharmacology of Ficus carica: A review. Pharm. Biol. 2014 Nov 1; 52(11):1487-503.

22. Krishna MG, Pallavi E, Ravi KB, Ramesh M, Venkatesh S. Hepatoprotective activity of Ficus carica Linn. leaf extract against carbon tetrachloride-induced hepatotoxicity in rats. DARU. 2007; 15(3):162-166.

23. Mawa S, Husain K, Jantan I. Ficus carica L. (Moraceae): Phytochemistry, Traditional Uses and Biological Activities. Evid Based Complement Alternat Med. 2013; 2013:974256.

24. Kawanishi K, Ueda H, Moriyasu M. Aldose reductase inhibitors from the nature. Curr. Med. 2003 Aug 1; 10(15):1353-74.

25. Manzanaro S, Salvá J, de la Fuente JÁ. Phenolic marine natural products as aldose reductase inhibitors. J. Nat. Prod. 2006 Oct 27; 69(10):1485-7.

26. de la Fuente JÁ, Manzanaro S, Martín MJ, de Quesada TG, Reymundo I, Luengo SM, et al. Synthesis, activity, and molecular modeling studies of novel human aldose reductase inhibitors based on a marine natural product. J. Med. Chem. 2003 Nov 20; 46(24):5208-21.

27. Saraswat M, Muthenna P, Suryanarayana P, Petrash JM, Reddy GB. Dietary sources of aldose reductase inhibitors: prospects for alleviating diabetic complications. Asia Pac. J. Clin. Nutr. 2008 Dec 1; 17(4) ):558-65.

28. Matsuda H, Wang T, Managi H, Yoshikawa M. Structural requirements of flavonoids for inhibition of protein glycation and radical scavenging activities. Bioorg. Med. Chem. 2003 Dec 1; 11(24):5317-23.

29. Haraguchi H, Ohmi I, Fukuda A, Tamura Y, Mizutani $\mathrm{K}$, Tanaka $\mathrm{O}$, et al. Inhibition of aldose reductase and sorbitol accumulation by astilbin and taxifolin dihydroflavonols in Engelhardtia chrysolepis. Biosci Biotechnol Biochem. 1997 Apr 23; 61(4):651-4.

30. Singh R, Kaur N, Kishore L, Gupta GK. Management of diabetic complications: a chemical constituents based approach. J. Ethnopharmacol. 2013 Oct 28; 150(1): 51-70.
31. Kajal A, Singh R. Modulation of advanced glycation end products, sorbitol, and aldose reductase by hydroalcohol extract of Lagenaria siceraria mol standl in diabetic complications: an in vitro approach. J. Diet. Suppl. 2018 Jul 4; 15(4):482-98.

32. Kishore L, Kaur N, Kajal A, Singh R. Extraction, characterization and evaluation of Eruca sativa against streptozotocin-induced diabetic nephropathy in rat. Bangladesh J. Pharmacol. 2017 Jun 30; 12(2):216-27.

33. da Silva Morrone M, de Assis AM, da Rocha RF, Gasparotto J, Gazola AC, Costa GM, et al. Passiflora manicata (Juss.) aqueous leaf extract protects against reactive oxygen species and protein glycation in vitro and ex vivo models. Food Chem. Toxicol. 2013 Oct 1; 60:45-51.

34. Kishore L, Kaur N, Singh R. Renoprotective effect of Bacopa monnieri via inhibition of advanced glycation end products and oxidative stress in STZ-nicotinamideinduced diabetic nephropathy. Ren. Fail. 2016 Oct 20;3 8(9):1528-44.

35. Shimizu M, Ito T, Terashima S, Hayashi T, et. al. Inhibition of lens aldose reductase by flavonoids. Phytochemistry. 1984; 23(9):1885-8.

36. Ghamali M, Chtita S, Hmamouchi R, Adad A, Bouachrine M, Lakhlifi T. The inhibitory activity of aldose reductase of flavonoid compounds: Combining DFT and QSAR calculations. J. Tiabah Univ. Sci. 2016; 10(4):534-42.

37. Patil KK, Gacche RN. Inhibition of glycation and aldose reductase activity using dietary flavonoids: A lens organ culture studies. Int. J. Biol. Macromol. 2017; 98:730-8.

38. Aju BY, Rajalakshmi R, Mini S. Evaluation of antioxidant activity of Murraya koenigii (L.) Spreng using different in vitro methods. J. Pharmacogn. Phytochem. 2017; 6(4): 939-942.

39. Trifunschi SI, Ardelean DG. Flavonoid extraction from Ficus carica leaves using different techniques and solvents. Zbornik Matice srpske za prirodne nauke. 2013(125):81-6. 